\title{
RAZPRAVE
}

\section{OBRAVNAVA GEOGRAFIJE KOT ZNANOSTI PRI POUKU V OSNOVNI ŠOLI}

AVTOR

\section{Matjaž Geršič}

Znanstvenoraziskovalni center Slovenske akademije znanosti in umetnosti, Geografski inštitut Antona Melika, Gosposka ulica 13, SI - 1000 Ljubljana, Slovenija

matjaz.gersic@zrc-sazu.si

DOI: $10.3986 / G V 86102$

UDK: $910: 373.3$

COBISS: 1.02

\section{IZVLEČEK}

\section{Obravnava geografije kot znanosti pri pouku v osnovni šoli}

$V$ prispevku je prikazano, kako je v osnovni šoli obravnavan pojem geografije kot znanosti in njena logična zasnova. V analizo so bili vključeni osnovnošolski učbeniki za šesti razred ter učni načrt za geografijo. Obravnava logične zasnove posamezne znanosti namreč pomembno vpliva na učenčevo dojemanje vsebine predmeta in na morebitne težave pri razumevanju, ki se pojavijo v povezavi s tem. Sodobni cilj pouka geografije je učencem prikazati svet celostno in življenjsko ter jih opozoriti na mrežo prepletenih odnosov med različnimi prvinami pokrajine. V prispevku je nakazano, kako učencem predstaviti geografijo kot kompleksno znanost oziroma znanost prepletenosti odnosov v pokrajini.

\section{KLJUČNE BESEDE}

geografija, didaktika, znanost, učbeniki

\section{ABSTRACT}

\section{Treating geography as a science in primary-school instruction}

This article discusses how the concept of geography as a science and its logical structure are treated in primary schools in Slovenia. The analysis included sixth-grade geography textbooks and the geography syllabus. The treatment of the logical structure of an individual science has an important impact on students' conception of the subject content and any problems in understanding that may arise in this regard. The modern objective of geography instruction is to present the world to students comprehensively and realistically and to draw their attention to the network of interconnected relations between various elements within a region. The article suggests how to present geography to students as a complex science or a science about interrelations of landscape elements.

\section{KEYWORDS}

geography, teaching, science, textbooks

Uredništvo je prispevek prejelo 3. aprila 2014. 


\section{Uvod}

Eno od osnovnih didaktičnih pravil pri obravnavani nove učne teme je pojasnitev temeljnih pojmov. Enako pravilo velja tudi pri prvih urah novih predmetov tako na osnovnošolski kot srednješolski ravni. Vsako prvo šolsko uro določenega predmeta v dnevnik običajno napišemo »Uvod« ali »Uvodna ura«. Tako kot ima pričujoči članek uvodni del in tako kot imajo učne ure uvodni del, je nek uvod treba narediti tudi pri novem učnem predmetu, s katerim se spoznajo učenci. Poleg uvodnih navodil, predstavitve načina dela in ostalih tehničnih napotkov so uvodne ure običajno namenjene spoznavanju logične zasnove obravnavane vede. Pojasnitev logične sheme znanosti ter opredelitev njenega predmeta in metod, poleg zgradbe celotnega učnega predmeta, močno vpliva na predstavo učencev in dijakov o posamezni znanosti ter njenem poslanstvu.

\section{Geografija - zahteven pojem?}

Pojem geografija je eden izmed 99-tih pojmov, ki so zapisani v učnem načrtu za 6. razred osnovne šole (Učni načrt ... 1998; Resnik Planinc 201, 82). Po raziskavi Resnik Planinčeve je 41,8 \% učiteljev menilo, da spada pojem geografija med zahtevnejše oziroma težje razumljive pojme, med učenci pa je bilo enakega mnenja manj kot 25,4\% učencev (Resnik Planinc 2001, 98). Ugotovljeno je bilo, da med učitelji in učenci prihaja do velikega razkoraka pri definiranju zahtevnejših pojmov in gesel (Resnik Planinc 2001, 139). Po mnenju učiteljev so vzroki zahtevnosti geografskih učnih vsebin različni; $56 \%$ jih meni, da je vzrok v njih samih, med 35 in $40 \%$ jih je mnenja, da so vzrok bodisi slabi učni pogoji, učni načrti ali izbor učnih oblik in metod, le okrog $30 \%$ pa jih vidi razloge v učencih (Resnik Planinc 2001, 140).

Dobra polovica učiteljev meni, da so pojmi, določeni v učnem načrtu smiselni in potrebni za obdelavo ne glede na stopnjo zahtevnosti, $22 \%$ bi takšne pojme izločilo, $24 \%$ pa se obravnava zdi smiselna, če so nujni za izvedbo učnih ciljev, le učne oblike in metode je treba nekoliko prilagoditi (Resnik Planinc 2001, 140).

Resnik Planinčeva ugotavlja, da bi izmed 22 izbranih pojmov več kot $40 \%$ anketiranih učiteljev izključilo pojma »svoboden pretok ljudi, blaga in delovne sile« ter »svetlobno leto«, nekoliko manj na primer pojem "galaksija«, za izbris ostalih izbranih pojmov pa bi se odločilo manj kot $30 \%$ učiteljev. Večina pojmov izhaja iz fizičnogeografskih vsebin. Do tu mnenja o izključitvah pojmov niso posebej sporna, a zadeva postane nekoliko bolj zapletena pri pojmu "geografija«. $9 \%$ učiteljev namreč meni, da bi bilo treba pojem geografija izključiti iz učnega načrta za osnovno šolo (Resnik Planinc 2001, 141).

Naravno vprašanje, ki se na tem mestu zastavlja je, na kakšen način poučevati predmet, ne da bi obravnavali pojem predmeta samega? Morda bi bilo bolj smiselno poskusiti različne učne metode, oblike in tehnike ter na ta način razložiti pojem geografija, ali pa razmisliti o sodobnem razumevanju pojma geografija, ki seveda presega ustaljena pojmovanja.

\section{Spreminjanje koncepta geografije kot znanosti v šolski geografiji}

Geografija je kot veda stara več kot 2000 let (Vrišer 2002, 37). Poleg opisovanja na novo odkritih dežel in njihovega upodabljanja na zemljevidih, je bilo njeno poslanstvo tudi razlaganje in pojasnjevanje, kar je geografijo umestilo med znanosti (Klemenčič in Drozg 2005, 76). Cilji in nameni pouka geografije so različni. Lipovšek jih deli na »... spoznavanje domovine in sveta ter geografskih procesov $v$ njiju, obravnavo aktualnih vprašanj iz narave in družbe, ter pridobitev splošnih znanstvenih spoznanj ter spoznanj in metodologije raziskovanja, ki geografijo povezujejo z drugimi znanostmi ... " (Lipovšek 2008, 3). »... Način obravnave učne snovi je odvisen od prevladujočega koncepta specialne didaktike in aktualne usmerjenosti znanosti ... « (Medved 1973, 26). V preteklosti so se v geografiji zvrstili števil- 
ni koncepti, nekateri so $\mathrm{v}$ šolski geografiji pustili močan in neizbrisen pečat, nekaterih pa šolska geografija ni niti zaznala (Medved 1973).

V 19. stoletju je kot posledica raziskovanja in odkrivanja notranjosti Afrike, Avstralije ter Severne in Južne Amerike prevladovalo mnenje, da je šolska geografija dejansko regionalna geografija. Posamezne regije so bile obravnavane sistematično $\mathrm{z}$ vidika posameznih geografskih prvin, na koncu pa je sledila sinteza. Na začetku 20. stoletja so kritike in odpor proti takšnemu konceptu izoblikovali smer, imenovano smer dominantnih faktorjev, neke vrste dinamično regionalno geografijo. Pri vsaki regiji je v ospredje postavljen jedrni problem oziroma motiv (na primer: Finska: dežela tisočerih jezer, Irska: zeleni otok). Nova spoznanja in naraščanje obsega učne snovi je v 60-tih letih 20. stoletja vodilo v eksemplarično smer regionalne geografije. Koncept predvideva izdelavo tipologije, kamor bi umestili vse svetovne regije, potem pa bi kot vzorčne primere za posamezno regijo obravnavali izbrane države. Tudi ta koncept je bil deležen nekaterih kritik. V določenih pogledih je eksemplarični smeri podobna funkcionalistična smer, ki kot glavni smoter geografije navaja »... spoznavanje prostorske stvarnosti kot rezultat soodvisnosti in součinkovitosti različnih dejavnikov... « (Medved 1973, 26-27).

Mednarodna listina o geografskem izobraževanju, ki jo je leta 1992 izdala Komisija za geografsko izobraževanje Mednarodne geografske zveze, podaja dva različna koncepta geografskega izobraževanja, to sta regionalnogeografski in tematski pristop. Pri tematskem se predvideva regionalna osnova, poleg tega pa lahko vsebuje sistematski koncept (fizična in družbena geografija), problemski koncept (študija tekočih dogodkov z geografskega gledišča) ter sistemski koncept (družbeni in fizični sistemi ter ekosistemi) (Resnik Planinc 1993, 149-150). Sistematski koncept tematskega pristopa lahko enačimo s Hettnerjevo shemo (Drozg 2007, 68), ki jo je nemški geograf Alfred Hettner (1859-1941) leta 1907 predstavil v svojem učbeniku o geografiji Evrope (Hettner 1907). Predpostavil je, da je za regionalnogeografsko študijo v prvi fazi treba sistematično analizirati posamezne pokrajinske prvine, $\mathrm{v}$ drugi pa ugotoviti vzročne povezave med njimi (Popit 2005, 155). V novejšem času lahko v šolski geografiji v posameznih državah opazujemo ustaljen regionalnogeografski koncept, med sodobnejšimi pa izstopata pokrajinskoekološki in družbenogeografski koncept. Pojavljata se tudi zaznavna in vedenjska geografija oziroma geografija ravnanja. Posebno smer predstavlja humana oziroma družbena geografija, ki izpostavlja človeške motive in čustva (Kunaver 2005, 47-48).

Posledica različnih konceptov in pristopov je tudi različno definiranje pojma geografija. Klemenčič povzema tuje učbenike in leksikone ter navaja naslednje možne definicije: »... geografija preučuje organizacijo geografskega prostora ...; ... geografija ponuja poznavanje prostora in njegove organiziranosti...; ... geografija preučuje zakonitosti razvoja pokrajine in družbe v njej...; ... geografija preučuje razmestitev pokrajinskih elementov, jih vrednoti in modelira...; ... geografija na celovit način preučuje odnos družbe do narave ...; ... geografija preučuje zemeljsko površje kot življenjski prostor človeške družbe ..." (Klemenčič in Drozg 2005, 59). Slovenskim učiteljem je verjetno najbolj poznana definicija Igorja Vrišerja, ki geografijo opredeli kot "... vedo o zemeljskem površju ali zemeljski površinski sferi, ki ugotavlja razširjenost, vplive in medsebojno soodvisnost tistih prirodnih in družbenih pojavov oziroma faktorjev, ki sodelujejo pri oblikovanju zemeljske površinske sfere kot celote ali njenih prostorskih delov... " (Vrišer 2002, 5). »Katera opredelitev je pravilna? « se sprašuje Klemenčič in dodaja: »... Umetnik bi dejal stvar okusa, praktik stvar potreb, teoretiki pa skušajo razrešiti geografsko kvadraturo kroga ... « (Klemenčič in Drozg 2005, 59). Učitelj praktik je tako postavljen pred zahtevno strokovno vprašanje. Soočen je z različnimi znanstvenimi koncepti in mnogimi opredelitvami istega pojma. Na kakšen način torej učencem predstaviti pojem geografija in pot do geografskega spoznanja? Verjetno najlažje prek enotnega predmeta proučevanja - zemeljskega površja. Tega geografija obravnava na celovit, celosten, kompleksen način. Ker pa na zemeljsko površje vplivajo različni dejavniki, ki s součinkovanjem ustvarjajo zelo zapleteno zgodbo, pri preučevanju predmeta raziskave prihaja do mnogoterih razlik (Klemenčič in Drozg 2005, 59). Ne smemo pozabiti tudi na dejstvo, da, čeprav govorimo o površju, moramo to površje dojemati prostorsko in ne ploskovno (Klemenčič in Drozg 2005, 60). Temeljni gradivi, s katerima si lahko pomaga učitelj praktik, sta učni načrt in učbenik. 


\section{Razkol med idealom in stvarnostjo}

»... Koncept učnega načrta za geografijo $v$ slovenski šolski geografiji ima jasno prepoznavno zgradbo. Temelji na razumevanju geografije kot vede, ki je razdeljena na občo in regionalno geografijo, potem pa še na fizičnogeografske in družbenogeografske veje oziroma na celine in manjše regije oziroma na ožje specializirane smeri ..." (Popit 2005, 150). V osnovni šoli je obravnava predmeta geografskega raziskovanja in geografije kot znanosti umeščena na začetek 6 . razreda. V učnem načrtu so v vsebinskem sklopu Geografija se predstavi opredeljeni naslednji operativni cilji: »Učenec spozna, kaj je predmet proučevanja geografije in kaj je geografija, razume pomen geografskega znanja za življenje ter spozna način in organizacijo učnega dela (Učni načrt ... 2011, 8). Dosledno upoštevanje učnih ciljev je nujno za kakovostno izpeljan pouk. »... Učni cilji, ki vključujejo vzgojno in izobraževalno komponento, so sestavni del splošnega učnega planiranja in najpomembnejši regulator pouka ... (Strmčnik 2001, 203). Na podlagi učnih načrtov, katerih del so tudi učni cilji, so napisani učbeniki. Leta 2012 je bilo za šesti razred osnovne šole na slovenskem trgu na voljo pet učbenikov (slika 1), katerih avtorji na različne načine pristopajo $\mathrm{k}$ obravnavi geografije kot znanosti, njenih vsebin, metod in predmeta preučevanja.

V učbeniku Geografija za 6. razred (Kolenc Kolnik 2004) v uvodnem poglavju z naslovom Geografija se predstavi avtorica najprej oriše geografijo z zgodovinskega vidika, nato pa s sodobnega vidika. Poudari vprašanja, povezana $\mathrm{z} » .$. nastankom in spreminjanjem zemeljskega površja ter o povezanost med naravo in ljudmi... «. Pojasnjuje, da geografija preučuje tako »...življenje ljudi kot tudi naravnogeografske elemente ... «. Avtorica zastavi zanimiva raziskovalna vprašanja: kje je kaj, zakaj prav tam, kako se naravnogeografske prvine povezujejo med seboj in kako učinkujejo na življenje ljudi. Poudari medsebojno povezanost in soodvisnost naravnih in družbenih prvin. Na koncu podpoglavja opredeli razliko med predmetom geografije nekoč (vse o Zemlji) in danes (pokrajine). V drugem podpoglavju jedrnato opiše geografijo. Poudari vzroke in posledice delovanja naravnih in družbenih procesov na splošno in v konkretnih pokrajinah. V nasprotju $\mathrm{z}$ drugimi vedami geografija preučuje vse naravne in družbene sestavine ter njihovo medsebojno povezanost. V tretjem podpoglavju, ki učence uvaja v GEOKLUB, vsebine geografske vede predstavi v obliki drevesa, ki korenini na Zemlji. Posamezne veje drevesa ponazarjajo pomožne geografske vede (Kolenc Kolnik 2004, 9-12).

V učbeniku Moja prva geografija (Senegačnik 2012) sta uvodni tematiki namenjeni dve strani. Avtor najprej pojasni izvor imena, metode dela ter predmet preučevanja. Poudari povezanost med naravnimi in družbenimi pojavi ter geografijo predstavi kot edino vedo, ki hkrati preučuje obe vrsti pojavov, zato jo umešča tako v naravoslovje kot tudi v družboslovje. Za osrednji predmet proučevanja opredeli Zemljino površje kot prostor oziroma stičišče kamnin, prsti, vodovja, tovarn, naselij ... V posebnem okvirju pojasni delitev geografije na fizično, družbeno in regionalno, na koncu pa se dotakne tudi posebnih geografskih metod dela (Senegačnik 2012, 4-5).

Podobno so temeljni pojmi na dveh straneh predstavljeni tudi v učbeniku Raziskujem Zemljo (Verdev 2007). Avtorica najprej pojasni izvor imena ter razliko med geografskim preučevanjem nekoč in danes. Geografijo predstavi kot vedo, ki »... načrtno proučuje naravne in družbene pojave na Zemlji ... «. $\mathrm{V}$ osrednjem delu loči med pojavi, ki so predmet fizične geografije, in pojavi, s katerimi se ukvarja družbena geografija. Na koncu opredeli pojem geografije v sodobnem času, pri čemer izpostavi boljše razumevanje sveta in trajnostno rabo naravnega okolja (Verdev 2009, 6-7).

V učbeniku Geografija 6 (Baloh in Lenart 2011) v poglavju z naslovom Geografija se predstavi avtorja najprej pojasnita izvor besede, nato pa razliko med geografijo v preteklosti in sodobnosti. Poudarjeno je, da je geografija danes veda, ki »... proučuje pokrajino z vsemi prepletenimi razmerji med naravo in družbo ...«. Sledi pojasnitev pojma pokrajina, pokrajinskih prvin in dejavnikov, pri čemer je poudarjeno njihovo medsebojno součinkovanje. Delitev geografije na družbeno in fizično je prikazana shematično. Izpostavljena je tudi vsakdanja uporabnost geografskega znanja. Avtorja na koncu jedrnato definirata geografijo kot »... znanost, ki proučuje pojave in elemente v pokrajini ... (Baloh in Lenart 2011, 6-7). 


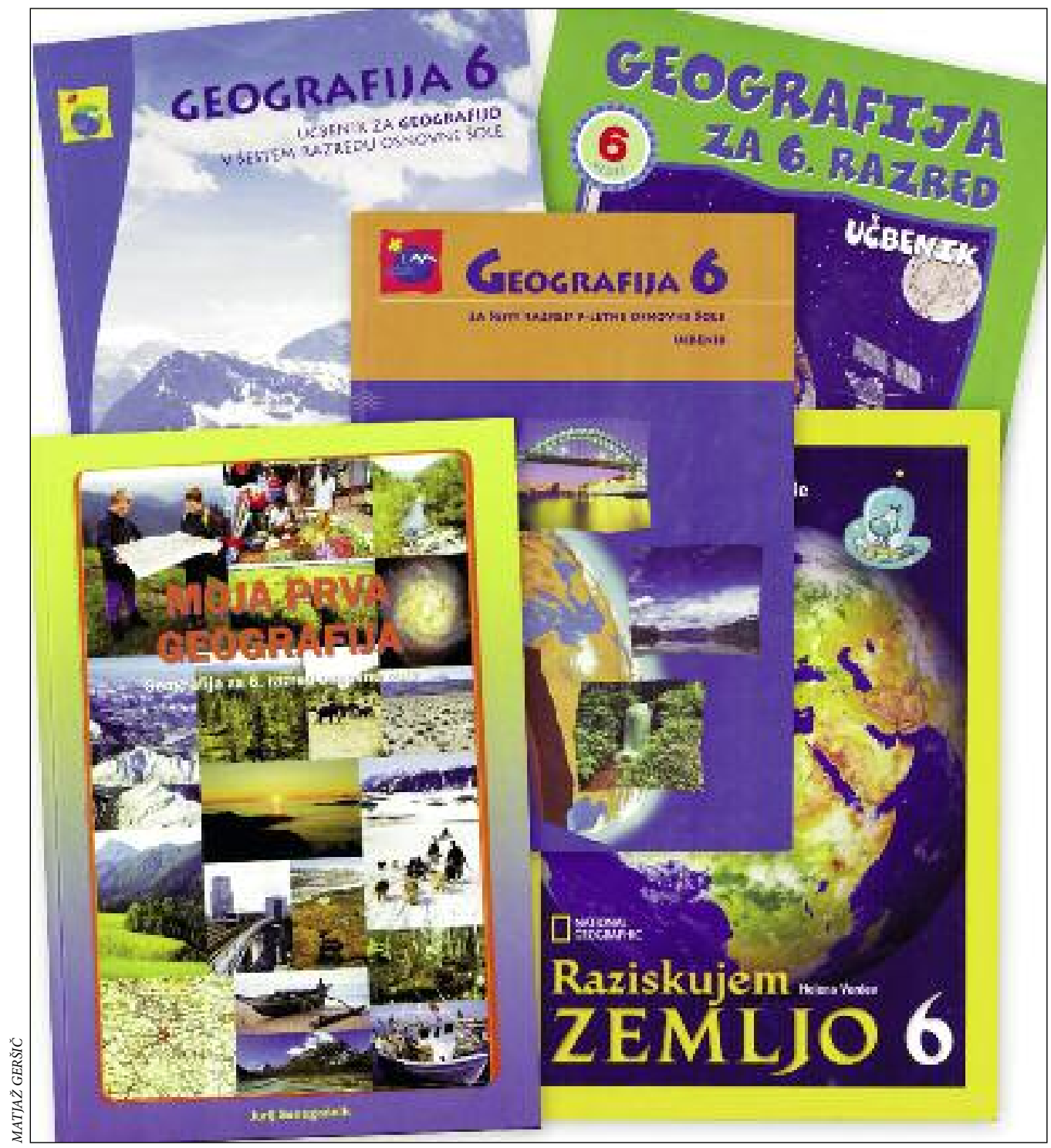

Slika 1: Aktualni geografski učbeniki za 6. razred osnovne šole.

Zadnji obravnavani učbenik, Geografija 6 (Bahar 2008), uvodnemu poglavju z naslovom Kaj je geografija namenja dve strani. Večji del tega prostora zavzema skica pokrajine, na kateri so s številkami označene pokrajinske prvine. Avtor v besedilu opredeli definicijo geografije in pravi, da se »... geografija ukvarja s preučevanjem tistih pojavov na Zemljinem površju, ki oblikujejo pokrajino ... «. Pojasni tudi pojem pokrajine (Bahar 2008, 8-9).

S horizontalno vsebinsko analizo (Komac, Zorn in Ciglič 2011, 62) lahko ugotovimo, da posamezni avtorji, z izjemo avtorice prvega predstavljenega učbenika, uvodnemu poglavju namenjajo dve strani. $\mathrm{V}$ preglednici 1 je prikazano, katere vsebine so v posameznem učbeniku vključene v uvodno poglavje. 
Preglednica 1: Vključenost posameznih vsebin v uvodno poglavje geografskih učbenikov za 6. razred osnovne šole.

\begin{tabular}{lccccc} 
& \multicolumn{7}{c}{ učbenik } \\
\cline { 2 - 5 } obravnavana vsebina & $A$ & $B$ & $C$ & $D$ & $E$ \\
\hline definicija & + & - & + & + & + \\
izvor besede & - & + & + & + & - \\
delitev na fizično in družbeno geografijo & - & + & + & + & - \\
regionalna geografija & - & + & - & - & - \\
geografske prvine & + & + & + & + & + \\
zgodovina geografije & + & + & - & + & - \\
metode dela & - & + & - & - & - \\
predmet raziskovanja & + & + & + & + & + \\
pokrajina & + & + & - & + & + \\
vzorčno-posledična zveza & + & + & + & + & - \\
geografija kot uporabna veda & + & - & + & + & - \\
shematičen prikaz geografije & + & - & + & + & + \\
\hline
\end{tabular}

A - Karmen Kolenc Kolnik: Geografija za 6. razred. Ljubljana, DZS, 2004.

B - Jurij Senegačnik: Moja prva geografija, geografija za 6. razred osnovne šole. Ljubljana, Modrijan, 2012.

C - Helena Verdev: Raziskujem Zemljo 6, Učbenik za geografijo v šestem razredu osnovne šole. Ljubljana, Rokus Klett, 2007.

D - Eneja Baloh, Bojan Lenart: Geografija 6, Učbenik za geografijo v šsttem razredu osnovne šole. Ljubljana, Mladinska knjiga, 2011.

E - Igor Bahar: Geografija 6, Učbenik za pouk geografije v šestem razredu osnovne šole. Ljubljana, Mladinska knjiga, 2004.

Ugotavljali smo, ali učbenik vsebuje kratko definicijo geografije, ali je pojasnjen izvor besede, ali geografijo deli na fizično in družbeno, ali je posebej izpostavljena regionalna geografija, ali so geografske prvine eksplicitno izražene, ali so predstavljene vsebine iz zgodovine geografije, ali so navedene metode geografskega dela, ali je izpostavljen predmet geografskega znanstvenega preučevanja, ali je v besedilu omenjena pokrajina, ali so omenjene vzročno-posledične povezave med geografskimi prvinami, ali je geografija ovrednotena kot uporabna veda in, ali je geografija kot stroka predstavljena tudi grafično?

\section{Ovire}

Horizontalna vsebinska analiza učbenikov je pokazala, da se njihovi avtorji pogosto še vedno držijo tradicionalnih predstav o geografiji kot znanosti.

Stroga delitev geografije na fizično, družbeno in regionalno po dualistični ali trialistični zasnovi pa ruši njen sodoben koncept kompleksnosti in enotnosti (Medved 1973, 25; Zgonik 1995, 29). Dolg mandat in prevladujočo vlogo regionalne geografije gre pripisati pokrajini kot temeljnemu predmetu raziskovanja ter njeni vlogi pri prikazu vzajemne povezanosti in soodvisnosti geografskih prvin (Medved 1973). Ohranjanje tradicionalne slovenske geografije pa hkrati povzroča preobsežnost koncepta učnega načrta (Senegačnik 1997). K preobsežnosti pripomorejo tudi posamezne prvine iz različnih obdobij razvoja geografije (Popit 2005, 150). Hettnerjeva shema, ki se pojavlja kot magna carta, ko želimo grafično ponazoriti geografijo kot vedo in njeno kompleksnost, je pogosto nekoliko napačno razumljena. Pokrajinske prvine, prikazane po plasteh, bralca na prvi pogled ne asociirajo na njihovo medsebojno prepletenost in nekoliko zameglijo geografsko kompleksnost. Na to je opozarjal že Medved (1973), kot anahronizem pa jo je označil Zgonik (1995). O primernosti njenega togega zaporedja 
namesto problemskosti in eksemplarnosti se sprašuje tudi Kolenc Kolnikova (1997). Klasična zamejitev Ritterjevih celin (Ritter 1861) dandanes onemogoča zadovoljiv prikaz dinamike in zgradbe sodobnega sveta. Za prikaz aktualnega sveta, kar je cilj sodobne šolske geografije, so pomembni odnosi in tokovi znotraj regije, med regijami, med družbo in naravo ter vloga posameznika kot pomembnega soustvarjalca geografskega okolja (Popit 2005, 155-156). Zaradi tega tradicionalna sistematična metodologija geografije ne more več zadovoljivo osvetliti pokrajinske stvarnosti (Klemenčič 1987, 83).

Vse to so ovire sodobne geografije, ki naj bi »... pronicljivo posegla v drobovje pokrajine in $v$ pokrajinskih sistemih iskala razvojne vzvode in okvire. "Predmet obravnave sodobne geografije naj bi bili pojmi, kot so privlačnost, stik, meja, središče, prag, ovira, mreža, vplivno območje, širjenje novosti, hierarhija, prehod, križišče, robnost, os (Klemenčič in Drozg 2005, 65).

\section{Sistemski pristop}

Kako torej v šolski geografiji preseči tradicionalnost geografije kot znanosti in poudariti njeno aktualnost, kompleksnost in celostnost?

Odgovor morda ponuja sistemski pristop, ki je odlična podlaga za učenje in razvijanje celostnega pogleda na pojave, za katere je značilno večje število spremenljivk, ki vplivajo na rezultate (Klemenčič 1992). Zavedati pa se je treba, da v didaktični sistem preprosto ni mogoče vnesti vsega, kar vsebuje znanstveni sistem, saj ta presega učne zmožnosti učencev, zato je nujna didaktična redukcija, torej poenostavitev celotnega znanstvenega sestava (Resnik Planinc 2001, 29). To velja tudi za sistemski pristop. Z vključitvijo sistemskega pristopa v vzgojno-izobraževalni proces lahko lažje odgovorimo na izzive sodobne družbe. Geografija je veda, ki obravnava sodobne izzive, zato je sistemski pristop dobrodošel pri obravnavi temeljnega predmeta raziskovanja, to je regije oziroma geografskega okolja (Popit 2005, 162-163). Sistemska teorija daje odgovore znanosti na vse bolj zapletene odnose v družbi ter med naravo in družbo. Geografe opominja na temeljna izhodišča geografskega preučevanja ter na potrebo po kompleksnem in celovitem preučevanju geografskega okolja (Klemenčič 1987). Smisel in življenje sistemu dajejo medsebojni odnosi med prvinami. Prvine sistema je treba razpoznati in izmeriti njihovo moč. Zato je treba zavreči pristop, ki izpostavlja prvine geografskega okolja na tradicionalen način "po predalčkih « (Klemenčič 1987, 80-81). Sistemski pristop ima v vzgojno-izobraževalnem procesu dva pomembna smisla. Prikazuje namreč odnose in tokove ter omogoča predstavitev aktualnosti geografskih vsebin, hkrati pa razvija spretnosti kompleksnega geografskega mišljenja ter trajnejšega in prenosljivega znanja (Popit 2005, 162-163). Na ta način se ohranja tudi sodobni geografski koncept kompleksnosti. Takšen pristop je didaktično težji in zahtevnejši, a hkrati geografsko mnogo bogatejši in tudi tesneje povezan $\mathrm{z}$ geografsko znanostjo (Vresk 1987). Skladno z učnim načrtom smo geografijo kot znanost in njeno logično zasnovo učencem seveda dolžni predstaviti. Nikakor torej ne pride v poštev udejanjenje mnenja $9 \%$ anketiranih učiteljev iz raziskave Resnik Planinčeve $(2001,141)$, ki bi pojem geografija preprosto črtali iz učnega načrta. Učencem ga je treba predstaviti na primeren in zanimiv način!

Če sistemski pristop nekoliko poenostavimo in ga skušamo aktualizirati, lahko to storimo tako, da geografijo predstavimo kot pot od geografskih prvin do geografskega spoznanja. Geografske prvine, združene brez vselej istega zaporedja, si zamislimo kot kompostni kup, ki predstavlja pokrajino oziroma geografsko okolje. Geograf s svojim znanjem in metodami dela preučuje pokrajinske prvine, rezultat njegovega dela pa je geografsko spoznanje oziroma geografsko znanje. To spoznanje je kot nekakšen substrat $z$ višjo kakovostjo, ki lahko oplemeniti poznavanje pokrajine ter pozitivno vpliva na odnose in tokove znotraj nje.

S pomočjo takšne skice in učiteljeve razlage si bodo učenci morda lažje predstavljali logično zasnovo geografije kot znanosti, pri čemer bo uveljavljeno temeljno načelo o njeni enotnosti in kompleksnosti (Zgonik 1995, 23), hkrati pa ne bodo zabrisani raznovrstni (družbeni in naravni) vplivi na pokrajinsko pestrost. Temeljni predmet geografskega proučevanja ostajata geografsko okolje (Zgonik 1995, 30) oziroma pokrajina (Popit 2005, 162-163). Obogatimo ga z analizo sodobnih okoljskih sestavin družbenopolitične 


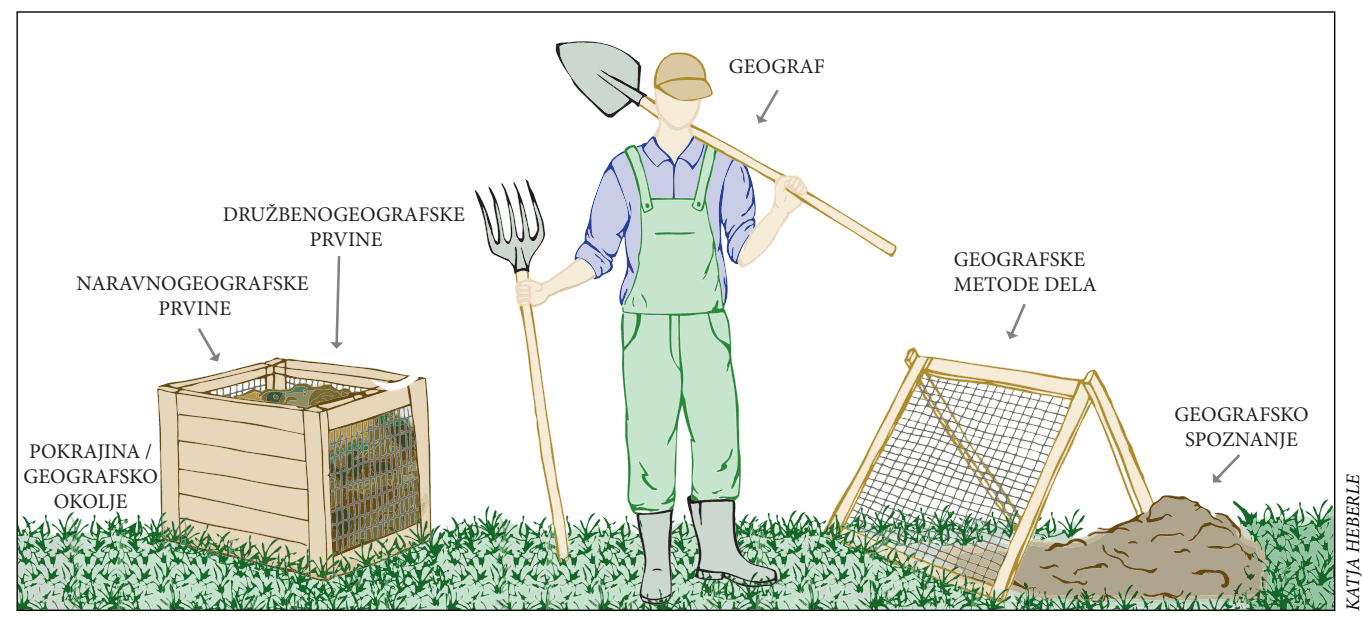

Slika 2: Pot do geografskega spoznanja.

in zgodovinske narave, več pozornosti pa lahko namenimo odkrivanju odnosov med posameznikom ali družbo in okoljem. Ohranja se tudi kompleksna vzročno-posledična povezanost v prostoru (Zgonik 1995, 30-33). Sodobna geografija je namreč tudi znanost o odnosih v konkretnem oziroma realnem prostoru (Zgonik 1995, 36), ki jih dojema kot substrat pojavov in njihove povezanosti v pokrajini (Drozg 2007, 76). Tako se izognemo skrbi, da bi posredovanje geografske snovi zvodenelo v običajno topografijo (Zgonik 1995, 34) in tako ne preseglo deskriptivne metode geografske znanosti iz preteklosti.

Dejstvo je, da so geografske prvine v konkretnem prostoru povezane, geografskih pojavov in njihovih sestavin pa ne moremo obravnavati ločeno. Sodobna geografija se je dvignila na višjo raven, na obravnavanje stvarnih geografskih dejavnikov kot geofaktorjev v stvarnem prostoru ali pokrajini, v medsebojni soodvisnosti in njihovi funkciji (Zgonik 1995, 47).

Sistemska teorija omogoča tudi nov način razumevanja pokrajine in nas pri vsakem geografskem preučevanju sili, da razmišljamo o celovitosti in kompleksnosti (Klemenčič 1987). Posredovanje kompleksne geografske podobe sveta ni samo naloga geografske stroke, temveč vzgojno-izobraževalnih ustanov nasploh (Zgonik 1995, 46). V nekoliko podrejen položaj je postavljeno genetično načelo, kar lahko omilimo z izbranimi konkretnimi primeri in kakovostno razlago učitelja.

"... Geografija kot znanost že po svoji strukturi in vsebini po notranji logiki in silnicah povezuje različne ravni med naravnimi in družbenimi pojmi in pojavi. Njena vsebina je zelo različna. Utemeljenost, čim bolj povezati družbene in naravne značilnosti v soodvisnosti in notranjem izvoru na konkretnem geografskem prostoru, je nujna tudi zaradi heterogenosti samih geografskih dejstev. Spoznanja, ki jih tako posredujemo, ne ostajajo izolirana in omejena. Korelacija geografskih spoznanj s spoznanji drugih predmetnih področij razvija $v$ učencih širše kompleksnejše mišljenje. Sodobno življenje ne pozna izoliranega predalčkastega mišljenja. Iz didaktično in spoznavnih, pedagoških in notranje znanstvenih vzrokov smo pogosto primorani primarna znanstvena dejstva in spoznanja različnih znanstvenih področij med seboj povezovati, še posebej, ker to zahteva sodobno življenje ...« (Zgonik 1995, 80).

\section{Sklep}

Geografija je predmet, v katerem se enakovredno prepletajo družboslovna in naravoslovna znanja, zato ima pomembno mesto v šolskem kurikulumu. Šolajoči se mladini približa čedalje bolj zapleten in hkrati usodno povezan svet sedanjosti in prihodnosti. To je velik izziv in hkrati velika odgovornost, 
ki jo ima geografija $v$ šoli. Zato spremembe normativnih dokumentov (učnih načrtov, učbenikov) še ne zagotavljajo, da bi šolska geografija to odgovornost tudi prevzela. Potrebne so spremembe v ustaljenih in zakoreninjenih pojmovanjih ter pogledih strokovnjakov in učiteljev, kar pa ni lahko doseči (Marentič Požarnik 2005, 22). Geografija se spreminja, razvija, išče nove poti in vsebine. Zaradi narave geografije, ki stremi, da je predmet njene obravnave in njenega raziskovanja vselej aktualen sodobni svet, v njej kot vedi ni absolutnosti, popolnosti in trajnosti. To velja tudi za šolsko geografijo (Popit 2005, 150). Geografija mora učencem svet prikazati celostno, življenjsko ter jih opozoriti na prepletenost odnosov med različnimi vidnimi in nevidnimi pojavi v njihovi okolici, katere del so tudi sami. Takšna geografija je učencem življenjska, saj se dotika tudi njihovih vsakodnevnih problemov, skrbi, interesov in veselja (Popit 2005, 165). Za takšno razumevanje tradicionalni pristopi niso dovolj. Strogo oklepanje strukture geografske znanosti v šolski geografiji zagotovo ne prinaša pozitivnih učinkov. Preobsežnost in zahtevnost izbranih vsebin med učenci mestoma povzroča odpor (Resnik Planinc 2001, 173-182). Poslanstvo geografske znanosti in didaktike je zastopanje geografske kompleksnosti in celovitosti (Zgonik 1995), z dodanim interdisciplinarnim pristopom pa je geografija tista veda, ki bogati znanstveno pokrajino (Resnik Planinc 2011).

$\mathrm{Na}$ koncu so seveda učitelji praktiki še vedno tisti, ki morajo geografijo »na svojem terenu«, torej $\mathrm{v}$ razredu, učencem predstaviti tako, da zadostijo znanstveni korektnosti, pri čemer naj svojo razlago prilagodijo sposobnosti dojemanja učencev.

\section{Viri in literatura}

Bahar, I. 2008: Geografija 6, Učbenik za pouk geografije v šestem razredu osnovne šole. Ljubljana. Baloh, E., Lenart, B. 2011: Geografija 6, Učbenik za geografijo v šestem razredu osnovne šole. Ljubljana. Drozg, V. 2007: Prispevek h gospodarski geografiji Slovenije. Revija za geografijo 3, 1-2. Maribor. Hettner, A. 1907: Grundzuüge der laänderkunde. Europa. Leipzig.

Klemenčič, M. M. 1987: Sistemska teorija: pot k novi regionalni geografiji? Teorija in metodologija regionalne geografije. Ljubljana.

Klemenčič, M. M. 1992: Sistemska teorija in geografija v srednji šoli. Geografija v šoli 2. Ljubljana.

Klemenčič, M. M., Drozg, V. 2005: Geografija - njeno poslanstvo in pomen. Slovenska šolska geografija s pogledom $\mathrm{v}$ prihodnost. Ljubljana.

Kolenc Kolnik, K. 1997: Naloge didaktike geografije: nekatere današnje prednosti in slabosti pouka geografije. Geografija v šoli 6, 2-3. Ljubljana.

Kolenc Kolnik, K. 2004: Geografija za 6. razred. Ljubljana.

Komac, B., Zorn, M., Ciglič, R. 2011: Izobraževanje o naravnih nesrečah v Evropi. Georitem 18. Ljubljana. Kunaver, J. 2005: Novejša mednarodna prizadevanja za sodoben pouk geografije, posebej o mednarodni listini o geografski vzgoji in izobraževanju. Slovenska šolska geografija s pogledom v prihodnost. Ljubljana.

Lipovšek, I. 2008: Didaktične ponazoritve geografskih procesov. Geografija v šoli 17-1. Ljubljana.

Marentič Požarnik, B. 2005: Vpetost v sodobna pojmovanja učenja in pouka - nujnost in hkrati izziv za geografsko izobraževanje. Slovenska šolska geografija s pogledom v prihodnost. Ljubljana.

Medved, J. 1973: O novi orientaciji geografije kot učnega predmeta. Geografski obzornik 20, 1-2. Ljubljana.

Popit, S. 2005: Izzivi sodobne geografije za geografsko vzgojo in izobraževanje. Slovenska šolska geografija s pogledom $\mathrm{v}$ prihodnost. Ljubljana.

Resnik Planinc, T. 1993: Mednarodna listina o geografskem izobraževanju. Geografija v šoli 3. Ljubljana.

Resnik Planinc, T. 2001: Zahtevnejše geografske učne vsebine kot izobraževalni problem. Doktorsko delo, Filozofska fakulteta Univerze v Ljubljani. Ljubljana.

Resnik Planinc, T. 2011: Perspektive prihodnosti v geografskem izobraževanju. Geografija v šoli 20-3. Ljubljana. 
Ritter, C. 1861: Geschichte der Erdkunde und der Entdeckungen. Berlin.

Senegačnik, J. 1997: Kurikularna prenova pouka geografije v srednješolskih programih, kjer je 210 ali več ur geografije. Geografija v šoli 6, 2-3. Ljubljana.

Senegačnik, J. 2012: Moja prva geografija: geografija za 6. razred osnovne šole. Ljubljana.

Strmčnik, F. 2001: Didaktika: osrednje teoretične teme. Ljubljana.

Učni načrt za osnovno šolo 1998. Zavod Republike Slovenije za šolstvo. Ljubljana.

Učni načrt za osnovno šolo 2011. Zavod Republike Slovenije za šolstvo. Ljubljana. Medmrežje: http://www.mizs.gov.si/fileadmin/mizs.gov.si/pageuploads/podrocje/os/prenovljeni_UN/UN_ geografija.pdf (12.6.2014).

Verdev, H. 2009: Raziskujem Zemljo 6, Učbenik za geografijo v šestem razredu osnovne šole. Ljubljana. Vresk, M. 1987: Geografski koncept - pokušaj pojednostavljene reinterpretacije. Geografski glasnik 49-1. Zagreb.

Vrišer, I. 2002: Uvod v geografijo. Ljubljana.

Zgonik, M 1995: Prispevki k didaktiki geografije. Ljubljana.

\section{Summary: Treating geography as a science in primary-school instruction} (translated by DEKS d. o. o.)

The basic teaching rule in covering a new topic is that the teacher must explain the basic concepts. When students are introduced to a new subject, the teacher must start by defining the concept of the new subject (or science or discipline), the topic of study, the methodology, and the logical structure of the science introduced. This influences how students perceive a particular discipline and its purpose.

The concept of geography is one of the 99 concepts included in the sixth-grade syllabus in Slovenia. In her study, Resnik Planinc establishes that $41.8 \%$ of teachers believe that this concept is among the more demanding ones, or those that are more difficult to understand. The corresponding share among students is $25.4 \%$. Just over half of the teachers believe that the concepts defined in the syllabus make sense and are necessary for discussion in the classroom regardless of their level of complexity. Twenty-two percent of teachers would take such concepts out of the syllabus, and $24 \%$ believe that discussing them makes sense as long as they are vital to meeting the learning objectives, but that learning forms and methods should be somewhat adjusted. Among those that would eliminate the more complex concepts from classroom instruction, $9 \%$ would also eliminate the concept of geography.

Geography is a discipline more than 2,000 years old that has changed throughout history. In addition to describing newly discovered lands and depicting them on maps, its purpose was also to explain and clarify, which classified it among the sciences. Some concepts from the past have left a strong mark on the geography taught in schools, whereas others have left no perceptible trace.

The International Charter on Geographical Education adopted in 1992 by the International Geographical Union's Commission on Geographical Education defines two different concepts of geographical education: regional studies and thematic studies. Thematic studies should have a regional base and may include a systematic approach (physical and human geography), an issue-based approach (the study of current issues from a geographical point of view), and a systems approach (physical systems, human systems, and ecosystems). The systematic approach of thematic studies can be equated with the Hettner scheme, according to which regional geography study first and foremost requires a systematic analysis of individual elements within a particular region, followed by the establishment of the causal relations between them. Various concepts and approaches result in various definitions of the notion "geography.« However, the subject of geographical study has remained the same throughout: the Earth's surface, which geography explores in a comprehensive, integrated, and complex manner.

The analysis of school textbooks showed that their authors often do not follow the traditional conceptions of geography as a science. The strict division of geography into physical, human, and regional 
geography under the dualistic or trialistic model undermines its modern concept of complexity and unity. The Hettner scheme, which springs up like the Magna Carta whenever one wishes to graphically present geography as a discipline and its complexity, is often slightly misunderstood. Medved already drew attention to this in 1976, and Zgonik (1995) referred to it as anachronistic. In addition, Kolenc Kolnik (1997) questioned the suitability of a scheme focusing on a rigid order instead of being problem-based and providing examples. The traditional delineation of continents by Carl Ritter can be used to satisfactorily present the dynamics and structure of today's world. The relations and currents within a region, between regions, and between society and nature, and the role of the individual as an important co-creator of the geographical environment are important for presenting the current world, which is the goal of modern school geography. The traditional systematic geographical methodology can no longer satisfactorily explain the regional reality.

How can the traditional nature of geography as a science thus be transcended in school geography, and how can its topicality, complexity, and comprehensiveness be highlighted?

The answer is provided by the systems approach, which forms an excellent basis for learning and developing a comprehensive view on phenomena that are characterized by a large number of variables affecting the results. The inclusion of the systems approach in the educational process makes it possible to respond to the challenges of modern society. Geography is a discipline that deals with these types of challenges, and therefore the systems approach provides a good solution for discussing the basic research subject (i.e., a region or a specific geographical environment). Systems theory provides scientific answers concerning the increasingly complex relationships in society and between society and nature. It draws geographers' attention to the basic premises of geographical study and to the need to study geographical environments in a complex and comprehensive manner. The relations between the elements is what gives sense and life to a system. Individual elements in the system must be identified and their power must be measured. Therefore, the approach that highlights traditional methods of highlighting the elements of a specific geographical environment must be discarded. The systems approach is important for the educational process for two reasons. First, it shows relations and currents and makes it possible to present current geographical material. Second, it makes it possible to develop the skills of complex geographical thinking and permanent transferrable knowledge. In this way it also helps maintain the modern geographical concept of complexity. In terms of teaching, this approach is more difficult and demanding, but also much richer and more closely connected with geography as a science.

If one slightly simplifies the systems approach and seeks to actualize it, this can be done by presenting geography as the path from geographical elements to geographical findings. Geographical elements, not always combined in the same order, can be conceived as a compost heap that represents a region or a geographical field. With their knowledge and work methods, geographers study these elements within the region, and the end result of their work is geographical findings or geographical knowledge. This knowledge is like a type of high-quality substrate, which can ennoble the conditions within the region and have a positive impact on the relations and currents in it. 